\title{
Democracy or intervention? Adapting orientations to development.
}

\section{Charles Neame*}

\author{
The Glasgow School of Art, Glasgow, United Kingdom
}

167 Renfrew Street, Glasgow, Scotland, G3 6RQ

Charles Neame is an educational developer working in the Scottish higher education sector. He worked originally as a lecturer in agricultural and environmental management, but completed a Doctorate in Education at the Institute of Education, University of London in 2009.

\section{Democracy or intervention? Adapting orientations to development.}

Many institutional cultures resist change, and academic developers take different approaches to overcoming such resistance, depending on the nature of the change and the institution, and their own characteristic styles and working preferences.

Variables influencing the successful introduction of innovation in academic practice include the inherent susceptibility of the institution to innovation, the nature of the innovation and the approaches of the change agents involved. This paper explores responses to resistant institutional culture; it presents a dichotomous model of educational development orientations, which emerged from an action research project within a research intensive university, and suggests that by adapting developmental orientations according to the context, developers can explicitly influence the responsiveness of the institution to innovation in academic practice.

Keywords: educational development; orientation; innovation

\section{Introduction}

An example of institutional reluctance to 'peer over the neighbour’s hedge’ is given by Graham Gibbs (2010),

\footnotetext{
*Email: c.neame@gsa.ac.uk
} 
who found a complete absence of inter-institutional comparisons of final year undergraduate projects or dissertations in UK institutions, despite the importance of this ubiquitous feature of UK bachelors' degrees in determining the quality and outcome of those programmes. It seems that Higher Educational Institutions (HEIs) have tended to develop a tremendous faith in their own practice which may make them reluctant to acknowledge a case for change based on the alternative practice of others. Institutional culture and behaviour require shared values which may cement positions for reasons of solidarity of the academic 'tribe' (Becher \& Trowler, 2001), in the face of any evidence suggesting the need for change.

Academic developers tasked with persuading members of academic practice communities (Wenger, 1998) to explore and adopt innovations in their practice have to find ways of overcoming the resistance implicit in institutional culture, by responding to the expectations of that culture.

This article draws on an investigation into how orientations of educational development and mechanisms for the dissemination and adoption of academic practice innovation may interact to reduce resistance to change (Neame, 2009).

That study explored a set of research questions relating to concepts of adaptive academic practice development, and how such development processes might respond sensitively to the diverse perspectives of different academic communities. It considered how differing institutional characteristics might encourage or inhibit that propensity for adaptation, using the metaphor of viral transmission (where the 'virus' represents a form of practice to which the institution or community has been more or less resistant). It also considered how such characteristics may be influenced, adapted or exploited to encourage the development of new practice. This paper deals primarily with this latter aspect of 'how to influence', which is considered to be essentially an issue of institutional culture, and how to respond effectively to it.

\section{Institutional culture and research context}

The research took place in a single, research-intensive institution, but it does not seek to generalise from a 
single case study to universal rules governing the nature of institutional cultures. Rather it explores the premise that within a given institutional context, the orientation applied to the educational development process can be flexibly adapted in response to that context.

In this particular university (and arguably, in others like it) there is a risk, given the dependence of some departments on research income, that teaching and student learning may be perceived as secondary activities. Academic staff may care deeply about student welfare and the quality of the learning experience, but there is a common presumption that improvements to teaching require resources to be diverted away from research, and that such a diversion of resource is not justified on economic grounds. This presumption is echoed in reports from other institutions and in other countries (see, for example, Leibowitz et al, 2011).

In the institutional context of the research reported here, there was an ambiguity about the nature and importance of academic practice insofar as it relates to teaching and student learning. Every department is likely to include a mix of pedagogic entrepreneurs and conservatives. Nonetheless, if the prevailing culture is one where all eyes are on the research prize, then even getting through the door to advertise the potential for innovation in, say, teaching or assessment methods, presents major obstacles to the educational developer.

In addition, even where the need for educational development is recognised by some members of a department, expectations relating to the nature of that development will differ; largely as a reflection of peoples' dominant institutional culture. For example, in a department where teaching is still perceived as transactional in nature, and based on a knowledge transfer model, participants in any professional development activity may well expect that activity to be transactional in nature also: "you (the developer) have three hours of my time to deliver a pre-determined set of knowledge or skill outputs".

At the same time, another colleague from the same department may come to the development event with the anticipation that it will bring new ideas and opportunities. The point is not so much about how different individuals from the same department may each have their own perspectives on the process and 
purpose of professional development, as about the potential for putting it to use when they return to the department.

These scenarios will be familiar to many who work in educational and academic development in higher education; the purpose of this paper is not to analyse scenarios of institutional culture, but to explore ways of responding to them which do not necessarily require a sophisticated analysis of cultural forms and drivers. Nonetheless, a brief overview of the landscape of organisational culture is a necessary starting point. Organisational culture has been defined as:

the specific collection of values, norms, beliefs and attitudes that are shared by people and groups in an organization and that control the way they interact with each other and with stakeholders outside the organization (Hill \& Jones, 1995, p. 381).

Much work has focused on culture in communities of practice. Examples of models and metaphors, developed as aides to understanding, include:

- Hofstede’s $(1980,1986)$ four dimensions of culture (Power distance; Uncertainty avoidance; Individualism vs. Collectivism; Masculinity vs. femininity).

- Handy’s (1995) four organisational cultural types (power, role, task, and person cultures).

- Morgan’s (2006) “Images of Organization” (including eight metaphors for the workings of organisations as: Machines; Organisms; Brains; Cultures; Political Systems; Psychic Prisons; Flux and Transformation; Instruments of Domination).

With specific reference to academic cultures, foremost amongst analyses is that of Becher's and Trowler's 'academic tribes and territories’ (2001). Describing tensions between traditional, disciplinary 'mode 1' knowledge structures and the state sponsored imperatives of inter-disciplinary 'mode 2' knowledge, they identify the risk of and resistance to fragmentation of academic identities, as academic roles multiply and 
career trajectories seem increasingly uncertain. Perhaps in response to this uncertainty, academic communities of practice may arrange themselves, or perceive themselves, in a range of 'organizational, cognitive and social' frameworks (ibid. p. 20). Although cultural differences may be disciplinary in origin, they may equally well reflect a diversity of national or local traditions (see, for example, Kelly, 1997).

Barnett (1990) emphasises the important role of institutional culture in higher education by lamenting its omission from policy analyses, going back to the Robbins report of 1963. To the ideas of organisational culture outlined above he adds the comment that academic cultures embody 'a taken-for-granted way of life, in which there is a reasonably clear difference between those on the inside and those on the outside of the community’ (ibid., p. 97).

Land (2004) summarises a number of models of organisational culture, insofar as they may be applied to academic communities and practice in institutions of higher education. He relates models and metaphors of culture - the ‘strategic terrain’ of the educational developer - to each other, but notes how complex understanding derives from this layering of multiple models. To model a process or idea is to simplify it, and the more it is simplified, the less accurately it represents the reality to which it relates. So, each additional model, layered on each precursor, reveals the complexity of the task which has prompted its creation. In this paper, however, I assume that simplification is of value, because a simple map that guides its bearer in roughly the right direction may be more useful than a complex map that only the most experienced user can decipher. An educational developer may do well, therefore, to be satisfied with a model of culture which, even if it's a simple one, 'does the job'.

As Morgan says:

Effective managers and professionals in all walks of life have to become skilled in the art of "reading" the situations they are attempting to organize or manage. This skill usually develops as an intuitive process... Skilled leaders and managers... are aware that new insights often arise as one approaches situations from 
"new angles" and that a wide and varied reading can create a wide and varied range of action possibilities (2006, p. xix).

So, determining a detailed model of academic culture may be less important to educational development than developing a set of intuitive responses to the broad sweep of cultural scenarios that a developer may face. The paper proceeds with this in view.

\section{Orientations of educational development}

The terms 'academic developer' and 'educational developer' are frequently used interchangeably. The distinction is essentially one of breadth, whereby academic development encompasses a more universal concept of the academic's role. This may include, for example, Boyer's four 'priorities of the professoriate' which embrace the scholarship of application, of discovery, of integration and of teaching (Boyer, 1990); and indeed more than this, according to Becher and Trowler, who suggest that Boyer's list should be extended to include 'leadership, management, administration and entrepreneurialism' (2001, p. 18). Educational development, on the other hand, may be said to be concerned primarily with the scholarship and practice of learning and teaching, and that is largely the contextual relevance of this article.

A framework for examining the educational developer's potential to influence, adapt and exploit characteristics of institutional culture grew out of Ray Land's investigation of educational developer orientations (Land, 2004). Land worked with educational developers in the United Kingdom to understand their 'orientations' in their work with their academic colleagues, using an in-depth interview methodology with 32 educational development practitioners. He coded the responses from these interviews into a classification of 12 'variations on practice' which he termed 'orientations to educational development'. This codification can be seen as a framework for analysing the relationships within, and features of, the various institutional networks responsible for implementing educational change within an organisation. This includes 
the type of working relationship on which the effective dissemination of good practice within a practitioner community is reliant.

Land's analysis illustrates the varied practice of educational development in a range of institutions. He identifies ‘a fragmented community of practice... [which is strongly influenced by] ...the organizational forms, academic cultures and subcultures within which they have to practise' (ibid. p. 12-13). In the research reported here the context of different institutional cultures is more directly relevant than the philosophical positions and perspectives of individual developers: the focus of interest is rather on their potential to respond to the organisational terrain within which they operate.

Land's analysis provides a taxonomy which facilitates the understanding of educational development within the institutions. The characteristics of developer orientations have the potential to describe the 'landscape' as well as individual actors within it. He cites Webb (1996) who says that:

'’Development' may be viewed as a site for a contest; it is not a unitary concept for which, one day, we will provide a model.'

Land echoes Lave and Wenger (1991) in saying that educational development involves 'situated learning' within differing and unique 'communities of practice'. The uniqueness of academic community cultures and practices immediately implies that the mode of engagement between an educational developer and a particular community needs to be tailored in response to that unique context. In turn, this suggests that educational development orientations may not necessarily be most usefully viewed as characteristics, or preferences, of educational developers, but as strategies for those developers to deploy as each different circumstance requires.

In describing his twelve orientations Land recognises the 'permeability' of these orientations and the likelihood of educational developers taking an eclectic approach 'as they traverse the differing academic and cultural terrain of their institutions' (Land, 2004, p. 126). The categories he devised for this analysis represent 
his interpretation of the perceptions of the educational developers that he interviewed. It is not the purpose of this paper to summarise and critique these categories, but to explore the application of the principle of adaptive categories to the implementation of effective educational development. In the research study referred to above, a simple model emerged which was used as part of an action research programme involving a number of staff from across the wider institution in the study. Its application is illustrated later through a case study of a developing Personal Development Planning (PDP) programme in one particular school. Both the action research method and the case study are outlined later in this paper.

The focus of a development orientation (on 'the educational practitioner', for example, or 'the student body') may result from the orientation taken, or it may be responsible for driving that orientation. It is not clear that one is cause, and the other effect. In practice, both are likely to influence the educational developer, depending on context. For example, if the needs of the student body are under scrutiny across the institution because of particular concerns about, say, quality of feedback, then the response of educational developers may be to emphasise professional competence: trying to embed some fundamentals of good feedback practice as widely as possible (based, for example, on widely accepted principles such as those set out by Nicol and Macfarlane-Dick, 2006). On the other hand, in their continuing professional relationships across the institution some of those same developers may tend to adopt a reflective practitioner or interpretivehermeneutic orientation, working to promote forms of engagement which are dialogic and undogmatic in nature. Table 1 illustrates the way in which development orientation and development focus may be related. 
Table 1 - Land's orientations and their focus

\begin{tabular}{|c|c|}
\hline Orientation & Focus \\
\hline $\begin{array}{l}\text { Managerial } \\
\text { (Development as an institutionally mandated process of } \\
\text { transition from one state of staff competence to another) }\end{array}$ & The Institution \\
\hline $\begin{array}{l}\text { Political - strategic } \\
\text { (Pragmatic: using networks to achieve a balance between } \\
\text { 'presence' across the institution and 'impact' in policy } \\
\text { delivery) }\end{array}$ & The Educational Development Unit (EDU) \\
\hline $\begin{array}{l}\text { Opportunist } \\
\text { (Change agent, exploiting shifts, cracks, or uncertainty in } \\
\text { the organisation) }\end{array}$ & EDU \\
\hline $\begin{array}{l}\text { Entrepreneurial } \\
\text { (Emphasis on achieving innovation, employability targets, } \\
\text { etc. Less focused on community building) }\end{array}$ & External stakeholders, e.g. employers \\
\hline $\begin{array}{l}\text { Researcher } \\
\text { (Educational development mobilised as an integrated part } \\
\text { of the academic community’s disciplinary development) }\end{array}$ & The specific discipline \\
\hline $\begin{array}{l}\text { Romantic (Ecological humanist) } \\
\text { (Emphasis on development of the individual) }\end{array}$ & The educational practitioner \\
\hline $\begin{array}{l}\text { Reflective Practitioner } \\
\text { "Emphasis is not on competence but on the process of } \\
\text { becoming more competent” (Gibbs, 1996). Development } \\
\text { as experiential learning for developers and their } \\
\text { colleagues. }\end{array}$ & The educational practitioner \\
\hline $\begin{array}{l}\text { Professional Competence } \\
\text { (Combines an 'apprenticeship' notion which aligns with } \\
\text { 'training' to serve learner needs) }\end{array}$ & The student body \\
\hline $\begin{array}{l}\text { Internal consultant } \\
\text { (Support for client-specified development, not externally } \\
\text { instigated intervention) }\end{array}$ & $\begin{array}{l}\text { Specific departments, groups or } \\
\text { individuals: 'clients' }\end{array}$ \\
\hline $\begin{array}{l}\text { Modeller-broker } \\
\text { (Good practice identified by developer, then 'promoted' } \\
\text { within a community of practice) }\end{array}$ & $\begin{array}{l}\text { Specific departments, groups or } \\
\text { individuals: 'clients' }\end{array}$ \\
\hline $\begin{array}{l}\text { Interpretive-hermeneutic } \\
\text { (Development as dialogue: interpretation and re- } \\
\text { interpretation by mutually respectful colleagues) }\end{array}$ & Concepts and understanding; life? \\
\hline $\begin{array}{l}\text { Provocateur } \\
\text { (Emphasis on change agents - typically drawn from within } \\
\text { an academic community itself) }\end{array}$ & The specific discipline \\
\hline
\end{tabular}

Author's note: Land suggests this focus in the section on 'Internal Consultant' (2004, p. 100), before his discussion of the final three orientations. In the case of these last three the focus is at my own suggestion. 


\section{Review of the orientations framework - intervention vs. democracy}

A review of this framework took place within an action research project, the purpose of which was to explore the process of adoption and dissemination of innovative practice in a particular university setting. The review led to the emergence of a related framework (explained below) with a simpler, dichotomous terminology, which could be used to suggest which mode, or 'meta-orientation' would be most appropriate in a particular situation. The dichotomy proposed was that of 'interventionist' versus 'democratic' orientations.

Despite the loss of the fine granularity of a subtler classification system, this polarisation allowed different scenarios to be viewed more essentially. Interventionist orientations focus more on mechanisms for active dissemination of good practice. They may tend towards a problem fixing, or knowledge transfer approach by an external agent. They are more likely to be transactional in nature. Democratic orientations focus on dialogue and trust, and assume a more participative engagement between developer and colleagues. The nature of problems and their potential solutions are open to debate and consensus based outcomes. In the process of defining this dichotomous model, Land's twelve orientations were categorised as in Table 2.

Some orientations appear to fall into both subdivisions, or to allow for movement between them. The political-strategic orientation, for example, is arguably interventionist in intent, in that it is premised on finding ways of implementing policy and ensuring widespread compliance with it. However, as a pragmatic philosophy it will adopt the approach which is most likely to be effective. It usefully illustrates the permeability of orientations and the potential for educational developers to be diverse in their approach. For example, someone whose preferred tendency is towards the reflective practitioner orientation may equally well be political and strategic in practice, when the situation so requires. 
Table 2 - A dichotomous classification of Land's orientations of educational development

\begin{tabular}{|c|c|c|}
\hline Orientation & Interventionist & Democratic \\
\hline Managerial/HRM & \multicolumn{2}{|c|}{$\begin{array}{l}\text { Focus on achieving institutionally } \\
\text { defined goals }\end{array}$} \\
\hline Opportunist & \multicolumn{2}{|c|}{$\begin{array}{l}\text { 'What works' for the educational } \\
\text { development unit (EDU)? Links with } \\
\text { strategic mode }\end{array}$} \\
\hline $\begin{array}{l}\text { Professional } \\
\text { competence }\end{array}$ & \multicolumn{2}{|c|}{$\begin{array}{l}\text { 'Training' to meet requirements of } \\
\text { student body. Links with managerial/ } \\
\text { HRM }\end{array}$} \\
\hline $\begin{array}{l}\text { Political- } \\
\text { Strategic }\end{array}$ & \multicolumn{2}{|c|}{ May switch between both 'modes' as conditions and goals dictate } \\
\hline Entrepreneurial & \multicolumn{2}{|c|}{ Concern to get things done, rather than concern with how to do it? } \\
\hline Modeller-broker & \multicolumn{2}{|c|}{$\begin{array}{c}\text { Elements of both modes: something of an interventionist stance in actively } \\
\text { promoting new practice; but does aim to work with others to develop new practice } \\
\text { mutually. }\end{array}$} \\
\hline $\begin{array}{l}\text { Internal } \\
\text { consultant }\end{array}$ & & $\begin{array}{l}\text { Collaborative discussions to solve } \\
\text { problems }\end{array}$ \\
\hline $\begin{array}{l}\text { Romantic } \\
\text { (Ecological } \\
\text { Humanist) }\end{array}$ & & $\begin{array}{l}\text { Focus on trust based relationship } \\
\text { building, and empowering individuals }\end{array}$ \\
\hline Researcher & & $\begin{array}{l}\text { Development arises from the power of } \\
\text { ideas, which in turn empowers the } \\
\text { beneficiaries. }\end{array}$ \\
\hline $\begin{array}{l}\text { Reflective } \\
\text { practitioner }\end{array}$ & & $\begin{array}{l}\text { Development arises from the } \\
\text { practitioner's reflective engagement } \\
\text { with practice, mediated by the } \\
\text { developer. }\end{array}$ \\
\hline $\begin{array}{l}\text { Interpretive- } \\
\text { hermeneutic }\end{array}$ & & $\begin{array}{l}\text { Development by conversation: } \\
\text { emphasis on mutuality and relationship. }\end{array}$ \\
\hline $\begin{array}{l}\text { Provocateur } \\
\text { (discipline } \\
\text { specific) }\end{array}$ & & $\begin{array}{l}\text { Situates educational development in the } \\
\text { language and frames of reference of the } \\
\text { educational practitioners themselves. }\end{array}$ \\
\hline
\end{tabular}

(Developed by author from Land, 2004)

\section{Transaction versus trust}

If the orientations above characterise the interaction between educational developers and their academic 
'client' communities, which characteristics of those communities influence the effectiveness of the interaction? Bearing in mind the complexity of models and metaphors of cultural mapping identified earlier, the cultural distinctions between communities, and between community members, might be represented by the simple model which emerged from this research, represented in Figure 1.

Figure 1: Continuum of 'message engagement', and shared communities of practice (Neame, 2009)

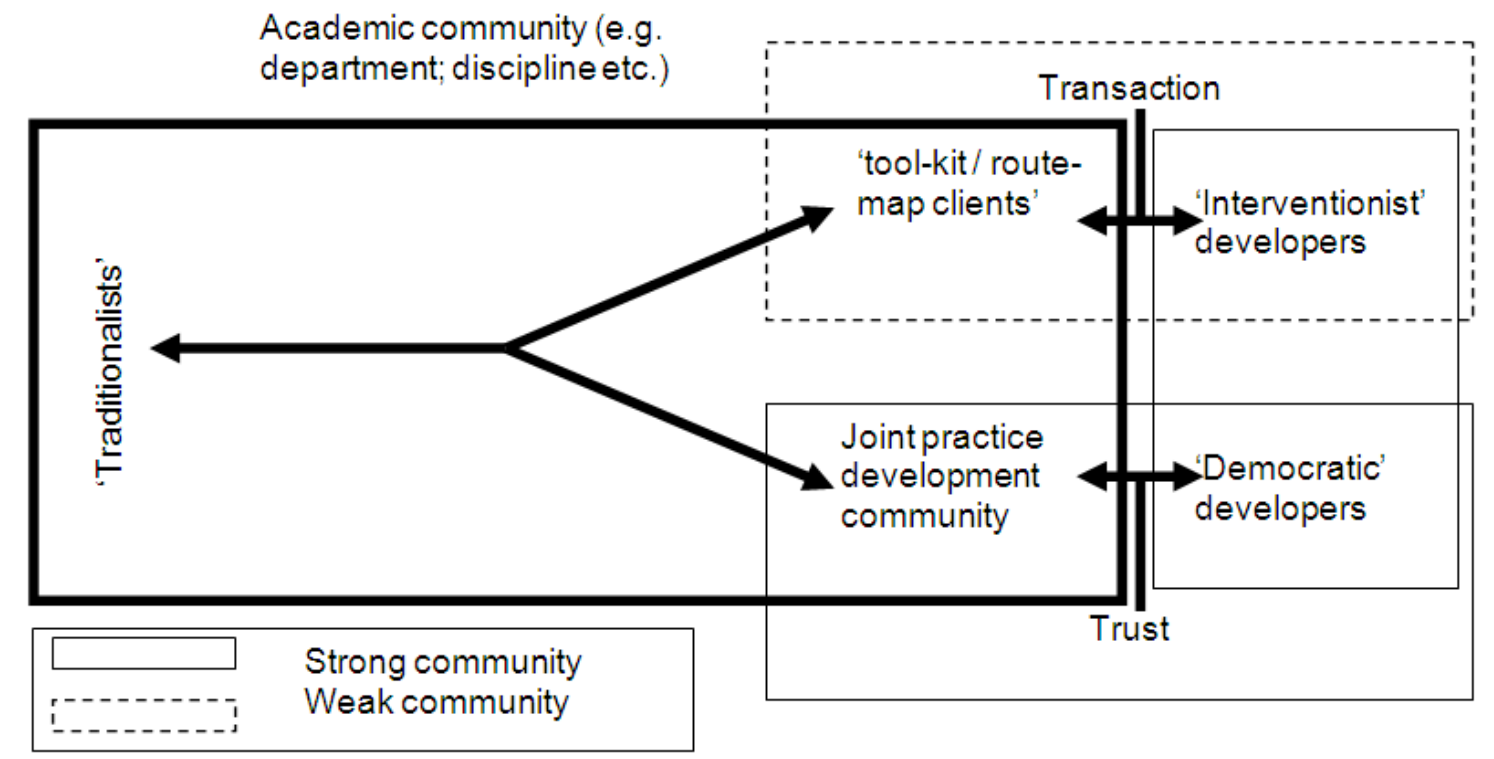

At this stage the model assumes that educational developers themselves are characterised by development orientations which suggest that they have a preferred approach to their work, namely (and in simplistic terms) either 'interventionist' or 'democratic'.

The figure shows a continuum of engagement within an academic community, with one forked end. At the single end are those whom we may caricature as 'traditionalists', who may be resistant to change and thus 'hard to reach' by educational developers. At the forked end of the continuum are those who are more open to change, but with alternative perspectives on how that change should be developed. Those who lean towards a transactional perspective are labelled here 'tool-kit' or 'route-map' clients: typically they want a clear problematisation of their practice with an explicit solution, and expect the developer to provide the 
necessary explanatory narrative, to allow them to 'upskill' as quickly as possible. They may or may not be very willing to accept change, depending on how it is presented.

Those who lean towards the trust perspective tend to a process of joint practice development (Fielding et al. 2005); they seek development on the basis of collaboration and consensus, and welcome the developer as a catalyst for open development of new ideas.

It follows that a sense of academic community is likely to be stronger amongst the latter than the former. The educational developer, despite typically being an 'outsider' from a different institution, or perhaps from a central educational development unit (EDU) within the university, is also more likely to be accepted as a member of the trust-based colleagues' own academic community, than is the case with the transaction-oriented colleagues.

Either way, the potential for influencing practice and innovation within the community as a whole will depend on the ability to either 'build trust' or 'complete transactions' successfully, as appropriate. To the extent to which that is achieved, others within the community, including the traditionalists, are more or less likely to explore and adopt new practice themselves.

The application and subsequent development of this model emerged from the research summarised below (Neame, 2009).

As previously discussed, the context of educational development interventions is significant. The research context in this case was that of a research-intensive institution. Furthermore, its academic community is engaged largely with engineering and natural science disciplines. The prevailing epistemological and methodological approaches to research in this environment were positivist and experimentally based, frequently involving hypothesis testing by the statistical analysis of quantitative data. While there is undoubtedly a great diversity of approaches to teaching within this community, a lack of familiarity with qualitative research methods frequently revealed a tendency to take a view that 'good 
teaching' arises from a blend of observation and common sense. "I did ' $\mathrm{x}$ ' with my students and they did well in their exams last year, so I'm doing 'x' again this year'.

In this situation, positions can be caricatured as either: "I know what I'm doing and don't need to be told" (the 'traditionalist' position, as in Figure 1); or "learning, like everything else, follows laws of cause and effect: show me the equivalent laws for teaching and learning and I will apply them" (the "tool-kit/route map client'); or, finally, "there's a lot of subtle stuff going on with my students which I don't fully understand how can we explain and exploit that to good effect?" (the joint practice development position). Representatives of all three positions were engaged in the research in one way or another.

The element of the research to which this particular analysis made a contribution, was a consideration as to how differing institutional characteristics (between different departments, for example) may be influenced, adapted or exploited to encourage the development of new practice. Participants were recruited to an action research group which contributed ideas drawn from their own practice, as well as introductions to their respective departments so that the practice of others could be drawn into the analysis.

The research identified Personal Development Planning (PDP) as a case study subject. PDP was a topical issue within the institution at the time, but one which was vigorously contested and debated. The opportunities for comparing forms of practice were varied; the potential for innovation and resistance to it were both evident.

\section{Engaging participants}

Participants were recruited from the academic staff into an informal network of colleagues, mainly from within the university. These were primarily course directors with a particular interest in PDP, but also others (some of whom were sceptics), who also held positions of influence on matters of course quality and design. The participants took part in a wide range of activities over two academic years, including individual interviews, School-based course directors’ meetings, and meetings of the core action research group. 38 
colleagues took part in total, of whom 10 (including the author) were members of the core action research group.

The activities identified above generated a substantial amount of data, principally in the form of texts (such as notes from meetings and transcriptions of interviews, which tended to capture the essence of points being made rather than verbatim records).

Land's framework (2004) as summarised above was used as a framework for analysis of the research participants' working environments. It was used to examine the orientations of a group of staff engaged (deliberately or otherwise) in an educational development process: in this case, the development and dissemination of PDP practice.

Yin (2003) proposes the case study as a method for exploring a phenomenon in its context. The action research project, focused on the development of academic practice relating to PDP in the context of a particular university, represents just such a phenomenon in context.

\section{Dissemination and adoption of academic practice innovation}

An example follows of the kind of development arising from the action research which illustrates the model of adaptive development orientations in practice.

As mentioned above, the case study context for the research was PDP within the university: the variety of forms it tended to take in different programmes and schools, the different perspectives held by staff, and so on. At one extreme the concept of PDP was viewed with distaste, as a worthless reductionism involving little more than the completion of a 'tick-box', skills-recording matrix, which resulted in no discernible benefit to the students. This situation arose from an earlier intervention across the institution, namely a central directive to 'embed' PDP in every university course, with very little developmental support designed to interpret and adapt it as a situated, meaningful construct. At the other extreme were instances where PDP was embedded successfully into the curriculum and valued by staff and students alike. 
The action research group represented a cross-section of staff, of whom many held strong views relating to PDP - broadly, that a university education should be inherently developmental in a personal as well as an intellectual and competence-focused way. The group thus existed to identify and exploit opportunities to disseminate this perspective more widely.

The example which follows relates to a taught postgraduate mechanical engineering programme, delivered in a School of the university where the view held by teaching staff of the PDP concept was particularly poor. The action research group included no representation from this school at all, which was a cause for concern, and introducing a more dynamic and productive PDP policy in the School was likely to prove challenging. The attempt to do so began with a short agenda item that I was allowed to introduce into one of the School's quarterly meetings for course directors. The intention was to introduce the topic of PDP to their agenda, but to leave them in control of their level of engagement with it. My engagement with these course directors as an educational developer was, in terms of the dichotomous interpretation of the development orientations model, predominantly interventionist at this stage:

- Until that point, the specific network of the School's course directors was essentially closed to me, with the exception of the chair of their committee. This colleague sat on other institution-wide bodies, which made him my sole point of formal contact with his group; he was unapologetically a PDP sceptic.

- I identified the challenge of PDP in his School as a strategic priority for educational development, if the School were to respond constructively to an emerging agenda around demonstrating key graduate attributes in an explicit and proactive manner. My approach to this key colleague, with a request for a 5 minute intervention on his course directors' meeting, was therefore both strategic and opportunist in nature.

At the meeting, I elicited views on PDP, rather than state a personal position, and explored the concern that 
PDP might increasingly be forced on the School as an issue requiring attention. I closed the item by issuing a general invitation to join in future discussions.

The viral principle, explored as another thread within the overall research programme, suggested that if one or two of these course directors proved to be 'susceptible' to the 'virus' represented by alternative PDP practices, then they might become vectors for carrying any future forms of such practice into the school itself. This subsequently proved to be the case: in response to my invitation, two course directors joined the discourse of the action research group. The engagement with these individuals moved swiftly to a mode which represented democratic development in practice: its dialogic nature was characteristic of the interpretive-hermeneutic orientation described by Land (2004), and stood in contrast to the transactional stance more typical of their School community as a whole. These colleagues subsequently provided introductions to others in their School; in particular, to the department head who was also course director for the mechanical engineering course to which the following example relates. I have called him Chris, for the purposes of this study.

An admitted sceptic, Chris agreed, on the basis of the introduction by one of the two proactive course directors identified above (whom I shall call Theresa), to a face to face discussion with me. Theresa was also the course director of a technical MSc course in Chris's school but an apparent distinction between them was her preparedness to engage in that analysis from a position of mutual interest, as opposed to transactional and somewhat defensive position taking. However, because of her respected status within her academic community, the report Theresa made to her fellow course directors on the potential of new PDP practice was not dismissed out of hand, but resulted in the meeting with Chris just mentioned. In turn, this meeting resulted in an agreement to pilot a new PDP element in his course. These were events I could not have engineered on my initiative alone. 
Strict boundaries and ground rules were laid out for the pilot (for example, limits on the time his staff were expected to spend implementing this development). Once these ground rules were agreed, Chris and the members of his course team engaged actively in the development of that programme.

From this point the engagement - or the development orientation - became fundamentally more democratic. Having received the approval of the department head as a result of a formal, somewhat transactional process, my relationship with the department had changed; I worked with the course team to plan the development of a PDP process that staff and students could all understand and value. The engagement between academic staff shifted swiftly from transactional to trust based (see Figure 2), and as an educational developer I moved into the academic community, from my original position outside it.

Figure 2: Potential for transition from interventionist to democratic development positions within more integrated communities of academic practice.

Academic community (e.g. department; discipline etc.)

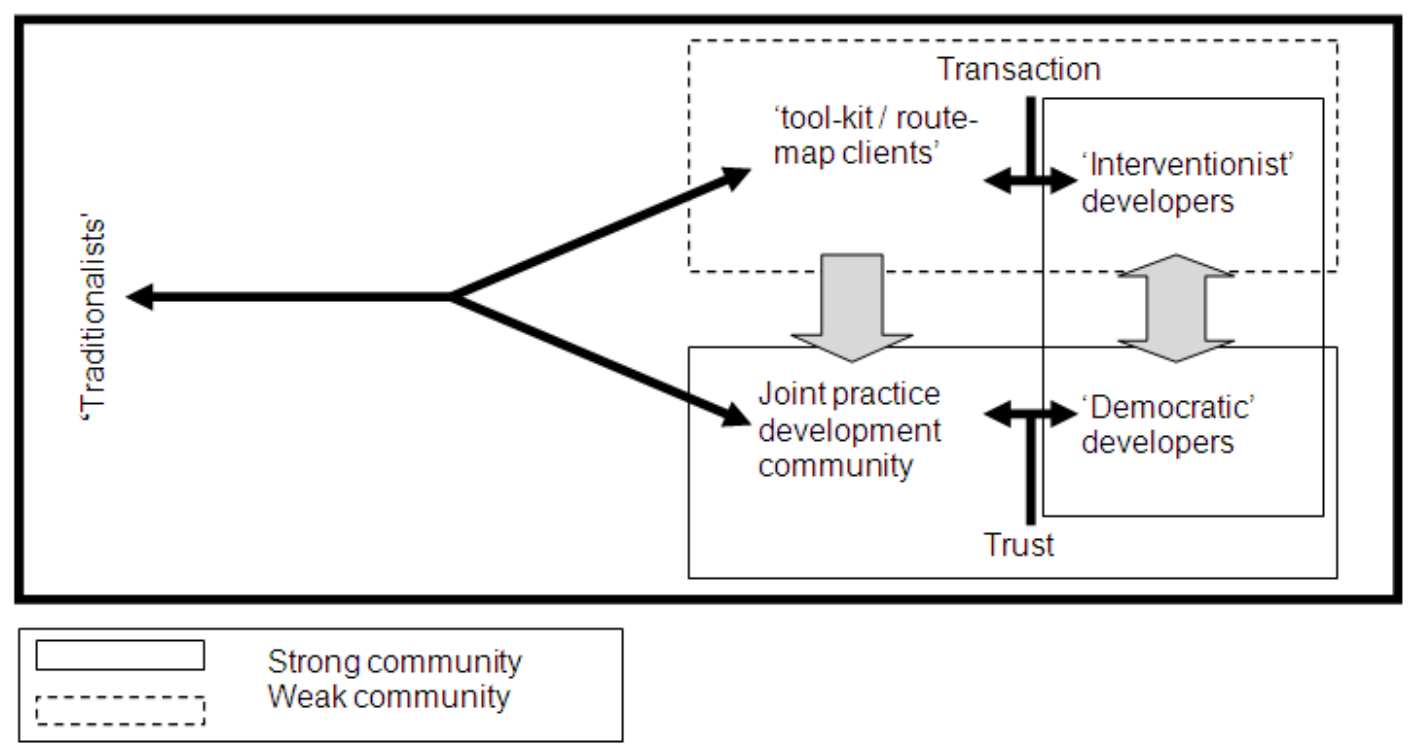




\section{Conclusions}

Orientations to educational development have an important bearing on the effectiveness of the intended development outcomes. While it is possible to analyse these orientations in a sophisticated and detailed manner, a simple dichotomous model of interventionist versus democratic orientation can help educational developers gauge the nature of their relationship with a 'client' community at a given moment, and within a given context.

The action research study reported here explored different forms and examples of PDP practice and how it is innovated across a particular institution. This experience suggested that educational developers, as change agents, will exert more influence over the innovation process by adapting their mode of developmental engagement, both according to the institutional culture of the academic community with which they are engaging, and according to the stage of the innovation they are helping to encourage. Thus at a certain stage strategic or opportunist interventions may be needed to make progress, while at another stage more democratic approaches involving dialogue and shared development of the agenda will work best.

Where institutional cultures are resistant to an innovation, at least two conditions for exerting influence effectively are necessary, or at least desirable.

First, it may be important to identify susceptible ‘carriers' (as of an infection, using the metaphor of spreading a virus to represent the dissemination of an innovation) who are trusted members of the relevant academic community. Whereas the educational developer may specifically be seen as an outsider whose innovations are threatening, 'carriers' (who have already been persuaded of the merits of an innovation) can more easily take that message back into their community and encourage its favourable reception from within.

Second, a preparedness on the developer's part to adopt the preferred orientation of the client or target community may be necessary, at least initially. If the latter see an innovative form of practice as a mechanism to be implemented scientifically and ‘under instruction' - as a ‘tool-kit' or 'route map' to be handed over as 
part of a discrete transaction - then it may be necessary to work within that perspective. As a consequence of interventions such as this, and of the influence of 'carriers' within the community, there is a potential for subsequent movement towards more democratic, trust-based processes of educational development within that same community. In terms of the model represented originally in Figure 1, it may be viewed with

amendments in Figure 2, showing how the 'tool-kit' or 'route-map' clients may shift towards a more mutually based mode of development, and how educational developers who begin their engagement with an academic 'client' community as outsiders, in some sense, may take their place more solidly within it.

\section{References}

Barnett, R. (1990). The idea of higher education. Buckingham: SRHE \& Open University Press

Becher T. \& Trowler, P. R. (2001). Academic tribes and territories: intellectual enquiry and the cultures of disciplines. ( $2^{\text {nd }}$ edition) Buckingham: SRHE \& Open University Press

Boyer, E. (1990). Scholarship Reconsidered: Priorities of the Professoriate. San Francisco: Jossey-Bass. The Carnegie Foundation for the Advancement of Teaching.

Fielding, M., Bragg, S., Craig, J., Cunningham, I., Eraut, M., Gillinson, S., Horne, M. Robinson, C., Thorp, J. (2005). Factors influencing the transfer of good practice. Nottingham: DfES.

Gibbs, G. (1996). Supporting educational development within departments. The International Journal for Academic Development, 1(1), 27-37.

Gibbs, G. (2010.) Dimensions of Quality. York: The Higher Education Academy.

Handy, C.B. (1995). Gods of management. London: Arrow Books.

Hill, C.W.L., Jones, G.R. (1995). Strategic management: an integrated approach. Boston: Houghton Mifflin.

Hofstede, G. (1980). Culture's Consequences: International Differences in Work Related Values. Beverly Hills: Sage.

Hofstede, G. (1986). Cultural differences in teaching and learning. International Journal of Intercultural Relations, 10 (3), 301-320.

Kelly, M. (1997). Teaching development in the cultural context of Hong Kong universities: What chances of success? International Journal for Academic Development, 2 (1), 24-34 
Land, R. (2004). Educational development: Discourse, identity and practice. Maidenhead: Society for Research into Higher Education \& Open University Press.

Lave, J. \& Wenger, E. (1991). Situated learning: Legitimate peripheral participation. Cambridge: Cambridge University Press.

Leibowitz, B., Cilliers, F., du Plessis, J., Kafaar, Z., van der Merwe, A., Viljoen, S. \& Young, G. (2011). Orientations to academic development: lessons from a collaborative study at a research-led university. International Journal for Academic Development, 16(1), 19-32

Morgan, G. (2006). Images of organization. London: Sage.

Neame, C. (2009). Applying a model of viral transmission to the development of professional practice in learning and teaching in higher education: a case of Personal Development Planning. Doctoral thesis, Institute of Education, University of London.

Nicol, D.J. \& Macfarlane-Dick, D. (2006). Formative assessment and self-regulated learning: A model and seven principles of good feedback practice. Studies in Higher Education, 31(2), 199-218.

Webb, G. (1996). Theories of staff development: development and understanding. The International Journal for Academic Development, 1 (1), 63-69.

Wenger, E. (1998). Communities of practice: Learning, meaning, and identity. Cambridge: Cambridge University Press.

Yin, R.K. (2003). Case study research: Design and methods. London: Sage. 